NOTE

BRAZILIAN JOURNAL OF OCEANOGRAPHY, 52(1):81-87, 2004

\title{
CONDITION OF THE BRAZILIAN SARDINE, Sardinella brasiliensis (STEINDACHNER, 1879) LARVAE IN THE SÃO SEBASTIÃO INNER AND MIDDLE CONTINENTAL SHELF (SÃO PAULO, BRAZIL)
}

\author{
June Ferraz Dias ${ }^{1}$; Catriona Clemmesen ${ }^{2}$; Bernd Ueberschär ${ }^{2}$; \\ Carmen Lúcia del Bianco Rossi-Wongtschowski ${ }^{I} \&$ Mario Katsuragawa ${ }^{I}$ \\ ${ }^{1}$ Instituto Oceanográfico da Universidade de São Paulo \\ (Praça do Oceanográfico, 191, 05508-900, São Paulo, SP, Brasil) \\ junedias@usp.br \\ ${ }^{2}$ Institut für Meereskunde an der Universität Kiel \\ (Düsternbrooker Weg, 20, Kiel, Germany D-24105)
}

Brazilian sardine is the most important target of purse seine fisheries along Southeastern Brazilian Bight. Fluctuations in the catch during the past 50 years have been noticeable (Matsuura, 1998; Cergole et al., 2002) and can be related to excessive fishery and to events during the egg production or in the initial development of the fish larvae, as predation, drift to unfavourable regions or starvation, acting together or in an independent way. Larvae in poor condition are thought to be more vulnerable to predation than healthy ones. So, investigations concerning condition could contribute to understanding oscillation in the abundance of fish larvae.

Previous studies on condition of sardine larvae in the Brazilian Bight recorded an interanual variation in the condition, with 7 to $13 \%$ of the larvae in weak condition, estimated by tryptic enzyme activity and RNA-DNA ratio. Relatively better larvae were related to the more pronounced summer intrusions of the South Atlantic Central Water over the continental shelf.

In the coastal São Sebastião area, north of São Paulo state, Sardinella brasiliensis larvae were the second species in abundance, $26 \%$ of all identified fish larvae. They were spread over the area, but higher concentrations were located in the south and southeast of the São Sebastião Island over the middle shelf, whereas in the west coastal areas the abundance was very low (Katsuragawa \& Dias, 1997). Due to the importance of the larvae of this species to the community structure of São Sebastião region, the aim of this study is to analyse the in situ feeding and nutritional condition of Sardinella brasiliensis, based on tryptic enzyme activity and RNA-DNA ratios, to increase information about the role of the São Sebastião middle and inner shelf during summer to the maintenance of larval field populations.

$\overline{\text { Contr. no. } 858}$ do Inst. oceanogr. da Usp.
The oceanographic cruise was carried out during February 1994 (austral summer), based on 43 oceanographic stations as a part of "Inner Shelf Oceanography of the São Sebastião region" project (OPISS Project). The area studied comprised the region around São Sebastião Island (Fig. 1). Profiles of temperature and electrical conductivity were continuously sampled as function of pressure with a CTD profiler in all stations per meter. The equipments used for fish larvae collection was the bongo net (500 and $300 \mu \mathrm{m}$ ) (Smith \& Richardson, 1977), to sample the water column, and a modified David neuston net (300 $\mu \mathrm{m})$ (David, 1965), to sample the sea surface till $7,5 \mathrm{~cm}$ depth. Net towing duration for bongo nets was 5 to 8 min., depending on the local depth, and to neuston net was a fixed time as $10 \mathrm{~min}$. Details can be found at Katsuragawa \& Dias (1997). Immediately after towing, if Brazilian sardine larvae were present, the nets were opened in a bucket, where ice cubs were added. The larvae were sorted on board, under naked eye, till a maximum time of $5 \mathrm{~min}$. after the end of the tows, and stored in liquid nitrogen. In the laboratory, larvae were checked for damages in the gut or in the body, measured (total length - TL mm) and processed.

In spite of the relatively good number of larvae sampled (119 in the south-southeastern and 31 in the west area) (Tables 1 and 2), the majority of the sardine larvae collected in the west area of São Sebastião Island presented clear signs of being dead before being sampled. These signs were the whitish colour of the musculature, the broken mandible, the absence of eyes and the separation between the gut and the body of the larvae itself. Larvae with these evidences totalised 67.7 and $23.5 \%$ of the larvae collected in the west and south-southeast of São Sebastião region, respectively, and were not considered in this study.

Tryptic enzyme activity and the amount of RNA and DNA per larvae were determined according to the analytical procedures described by Ueberschär 
(1988, 1995) and Clemmesen (1993), on entire individual homogenised fish larvae. Tryptic enzyme activity was measured in sardine larvae using a substrate (No-benzoyl-L-arginin-methylcoumarinylamide or $\mathrm{MCA}$ ) and the relative fluorescence was recorded 5 times every $2 \mathrm{~min}$. The resulting tryptic enzyme activity was given as the amount of hydrolysed substrate per time unit $\left(\mathrm{nmol} \mathrm{min}^{-1}\right)$ per larvae. Nucleic acids were extracted and purified from larval homogenates and the total content were fluorimetrically determined using ethidium bromide (EB) as a dye. RNA was enzymatically digested by RNase and the remaining DNA was determined with EB. Detailed instructions can be found at Moksness et al. (2000).

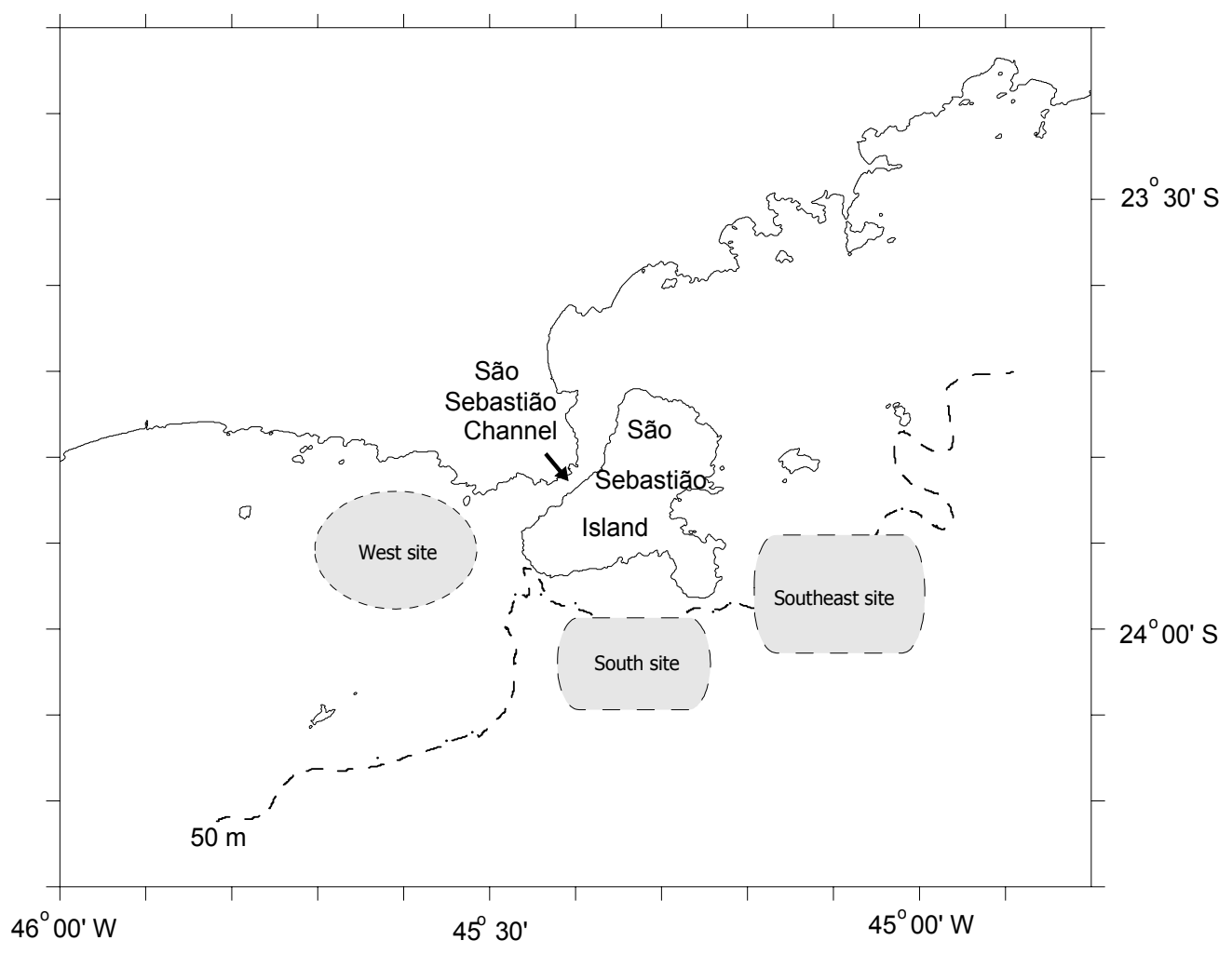

Fig. 1. Map showing the inner and middle continental shelf of São Sebastião region, São Paulo State, southestern Brazil.

Table 1. Number of tows of bongo and neuston net and positive stations for occurrence of Brazilian sardine larvae in south-southeast and west São Sebastião continental shelf during summer 1994.

\begin{tabular}{|c|c|c|c|c|c|c|}
\hline & \multicolumn{2}{|c|}{ South-Southeast site } & \multicolumn{2}{|c|}{ West site } & \multicolumn{2}{|c|}{$\begin{array}{l}\text { Total area of São } \\
\text { Sebastião }\end{array}$} \\
\hline & Bongo & Neuston & Bongo & Neuston & Bongo & Neuston \\
\hline number of stations sampled & 18 & 18 & 10 & 10 & 43 & 43 \\
\hline positive tows & 6 & 2 & 3 & 0 & 9 & 2 \\
\hline
\end{tabular}

Table 2. Number of Brazilian sardine larvae collected and analysed in south-southeast and west São Sebastião continental shelf during summer 1994.

\begin{tabular}{ccccccc}
\hline \hline & \multicolumn{2}{c}{ South-Southeast } & \multicolumn{2}{c}{ West } & \multicolumn{2}{c}{ Total } \\
\hline Number of larvae & $\mathrm{N}$ & $\%$ & $\mathrm{~N}$ & $\%$ & $\mathrm{~N}$ & $\%$ \\
analysed & 91 & 87.5 & 13 & 38.2 & 104 & 67.3 \\
dead before collected & 28 & 23.5 & 21 & 61.8 & 49 & 32.7 \\
total collected & 119 & 77.8 & 34 & 22.2 & 153 & 100 \\
\hline
\end{tabular}


For the first feeding to $9 \mathrm{~mm}$ total length Brazilian sardine larvae, the criteria available to evaluate condition is the laboratory experiments performed by Rossi-Wongtschowski et al. (2003). These experiments did not establish PNR ("point of no return") criteria. Although the laboratory results should be taken with caution (Chícharo, 1997), the values of tryptic enzyme activity and RNA/DNA of these unfeeding experiments should provide critical values below which field sardine larvae could be classified as in poor condition or as starving.

The equation used to evaluate larvae in bad condition using tryptic enzyme activity was: $\mathrm{Y}=$ $0.0158+0.0206 \mathrm{X}\left(\mathrm{r}^{2}=0.72\right)$, where $\mathrm{Y}$ is the amount of hydrolysed substrate per time unit $\left(\mathrm{nmol} \mathrm{min}^{-1}\right)$ per larvae and $\mathrm{X}$ is the total length of the larvae. The RNA-DNA ratio critical line taken from laboratory experiments was: $\mathrm{Y}=-0.39+0.27 \mathrm{X}\left(\mathrm{r}^{2}=0.94\right)$. Both equations were obtained from data of experiments where larvae of different ages were kept unfed for 2 days (Rossi-Wongtschowski et al., 2003).

The oceanographic situation during summer in the southeastern Brazilian Bight presents three water masses (Matsuura, 1986; Castro \& Miranda, 1998): the Coastal Water $(\mathrm{CW})$, with high temperatures and low salinity rates $\left(\mathrm{T}>24^{\circ} \mathrm{C}, \mathrm{S}<33\right)$; the offshore Tropical Water (TW) of the Brazil Current characterized by high temperatures and salinity rates flowing southward $\left(\mathrm{T}>20^{\circ} \mathrm{C}, \mathrm{S}>36.4\right)$; the South Atlantic Central Water (SACW), a typical oceanic water mass, characterized by temperatures below 20 ${ }^{\circ} \mathrm{C}$ and salinities above 36.4. When intruding onto the continental shelf, SACW occupies the bottom layer and mixes with the warmer and fresher Coastal Water (CW), delimiting a seasonal thermocline. Depending on the wind condition, the northern part of the studied area, around Cape Frio region $\left(23^{\circ} \mathrm{S}\right)$, can present an upwelling of SACW reaching the surface. Summer intrusions of the South Atlantic Central Water towards the coast are frequent off São Sebastião Island (Castro Filho et al., 1987), and its intrusions may promote high values of nitrate and an up to 10 fold increase in the primary production of the coastal water (Aidar et al., 1993).

The tendency of a triangular shape of the T$S$ diagram based on data of temperature and salinity taken on the oceanographic stations characterize the interactions of the three water masses mentioned above in the São Sebastião area on summer 1994: CW, TW and SACW (Fig. 2). In the area shallower than 50 $\mathrm{m}$ depth, that includes the west area (Fig. 1), the influence of the fresh Coastal Water is higher (Fig. 2A), whereas deeper than $50 \mathrm{~m}$ depths the influence of the cold South Atlantic Central Water over the southSoutheast area, could be noted interacting vertically with the hot and salty Tropical Water (Fig. 2B). The west coastal area of São Sebastião was vertically homogeneous, with a weak influence of the cold and salty water in the bottom layer (Fig. 3A and C), but the south-southeast area presented a two-layer structure, due to the presence of the cold and salty water in the bottom layer (Fig. 3B and D). Silva et al. (2001) showed that the intrusions of South Atlantic Central Water generate near-bottom thermoclines and haloclines in summer, in contrast to quasihomogeneous hydrographic conditions observed in the winter.

A

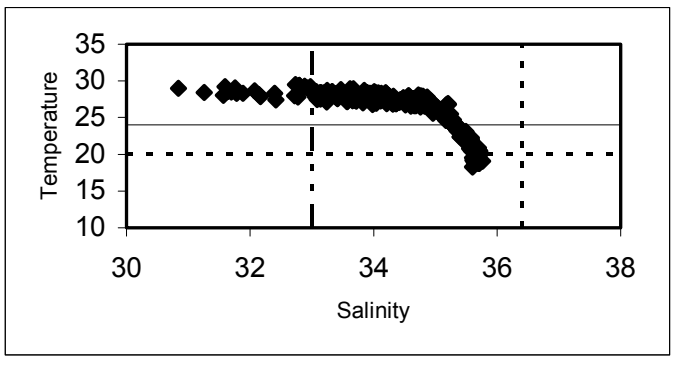

B

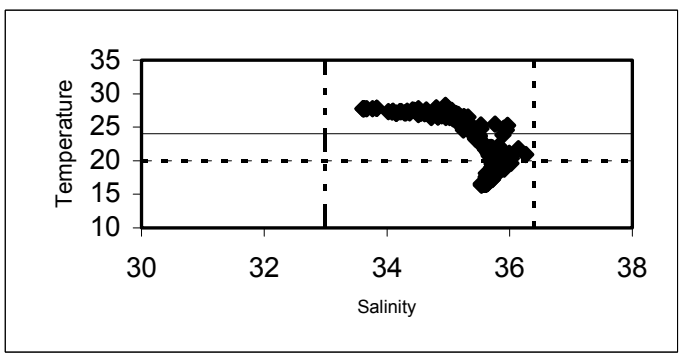

Fig. 2. Scattered T-S diagrams for the São Sebastião area, from west site (A) and southeast and south (B), during summer 1994. Vertical and horizontal lines delimit the water masses described in the text: Temperature $>24$ and Salinity $<$ $33=$ Coastal Water; Temperature $>20$ and Salinity $>36.4=$ Tropical Water; Temperature $<20$ and Salinity $>36.4=$ South Atlantic Central Water.

Field sardine larvae presented values of tryptic enzyme activity ranging from 0.1 to 19.3 (Fig. 4). Larvae bigger than $12 \mathrm{~mm}$ total length, showed a wide variation in the amount of hydrolysed substrate. Based in the laboratory experiments that established critical values for unfed $S$. brasiliensis, larvae from a wide length spectre ( 5 to $15 \mathrm{~mm}$ ) could be classified on weak feeding condition in the São Sebastião region, totalising $33.3 \%$ of the larvae collected along the water column. The smaller larvae (5 to $11 \mathrm{~mm}$ ) in preflexion and flexion stages (Kurtz \& Matsuura, 2001) attained $55 \%$ below laboratory critical line. On the other hand, sardine larvae sampled with neuston net presented small length variation (from 12 to $14 \mathrm{~mm}$ ) and all were in relatively better feeding 
condition. Mean values of tryptic activity per length considering larvae collected in west and southsoutheastern areas of São Sebastião Island reported larvae from 12 to $14 \mathrm{~mm}$ in comparatively poorer condition on the west side of São Sebastião Island (Fig. 5).

A

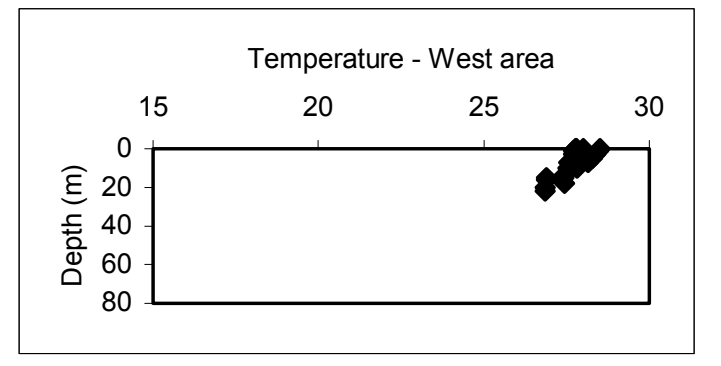

B

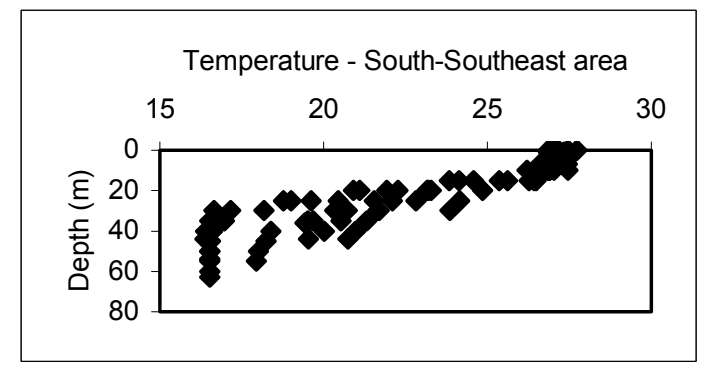

C

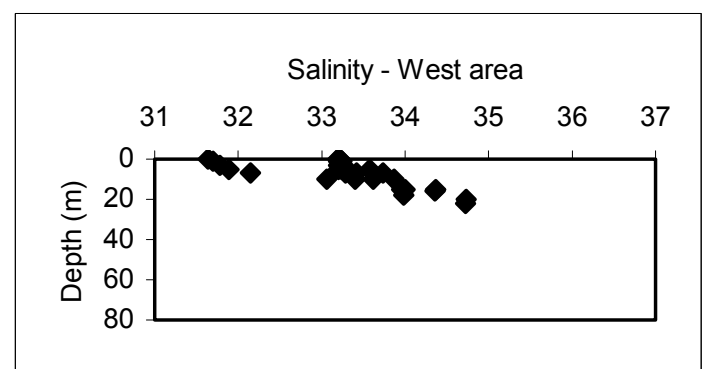

$\mathrm{D}$

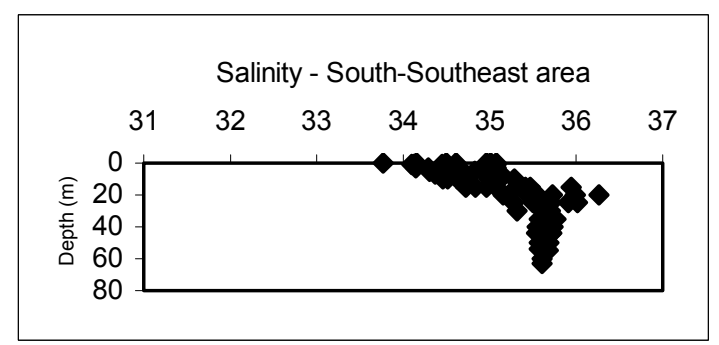

Fig. 3. Depth-temperature (A and B) and depth-salinity $(C$ and D) plots for west and south-southwest areas, respectively, around São Sebastião Island during summer 1994.
Individual RNA/DNA of field Brazilian sardine larvae captured on the water column with bongo net ranged from 0.5 to 3.3 (Fig. 6). There was a clear tendency of high values of RNA/DNA on the bigger larvae due to the larval growth. On the other hand, even larvae up $11 \mathrm{~mm}$ of the same length presented a variation on the RNA-DNA ratio with low and high values. The percentage of individuals presenting ratios below the critical laboratory calibration criterion was $57.9 \%$, showing that even in the bigger larval length groups there were larvae in relative poor nutritional condition. The neustonic larvae presented RNA-DNA ratios ranging from 1.0 to 4.0 , but in spite of the higher range, $55 \%$ of the larvae had RNA/DNA ratios below the critical line (Fig. 6). In comparison to the south-southeast, west area of São Sebastião Island presented lower values of RNA/DNA. All Brazilian sardine larvae collected in the west area were under the critical line (Fig. 7). In both areas it was possible to diagnose larvae in poor condition in the higher lengths groups.

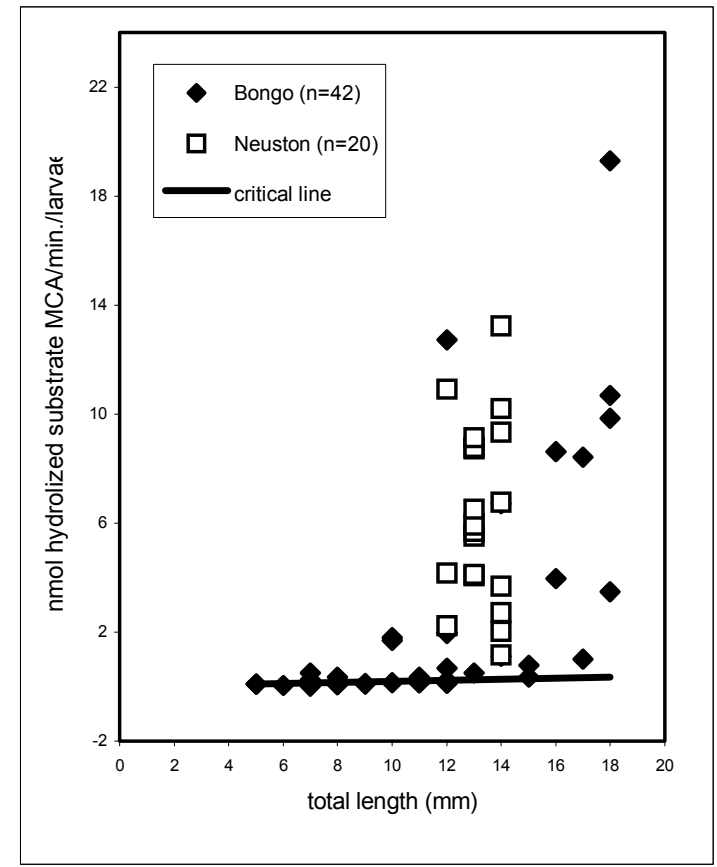

Fig. 4. Individual tryptic enzyme activity of field Brazilian sardine larvae collected in São Sebastião area. Critical line was taken from Rossi-Woingtschowski et al. (2003). Y axis was extended till -2 for clarify.

Normally, percentages of field larvae found in bad nutritional condition are low. Kimura et al. (2000) showed that there were no larvae of Japanese sardine (Sardinops melanostictus) under the PNR criterion collected in three years, but described that spatial distribution of the first feeding larvae between years 
were the main cause of differences in the condition of the larvae, estimated by RNA/DNA and daily growth rate in protein. They suggested that Kuroshio waters provide better feeding opportunities for the first feeding larvae in comparison to coastal waters. Previous studies showed that nutritional condition of $S$. melanostictus larvae collected from the offshore of the Kuroshio current were relatively poorer than that from coastal side of the same current (Shimizu et al., 1989). Chícharo $(1997,1998)$ could find differences in RNA/DNA in Iberian sardine larvae (Sardina pilchardus) among areas off southern Portugal: higher percentages of starvation were found in areas of low temperature, that increases the larval life duration and also the starvation probability, whereas lower starvation were related to the areas of estuarine influence, considered as a contributor to the high rates of zooplankton production. Regardless of larval good condition, Chícharo et al. (1998) related poor recruitment of $S$. pilchardus with unfavorable advection from their nursery area off north coast of Spain.

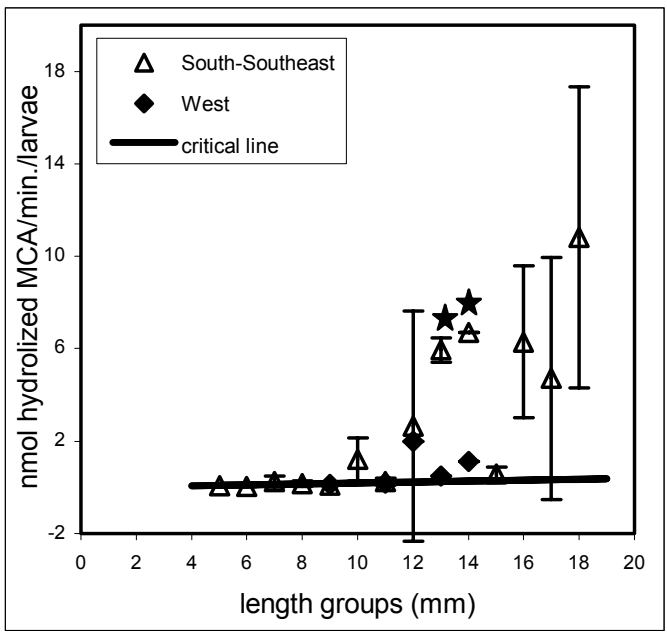

Fig. 5. Mean values of tryptic enzyme activity by length groups of field Brazilian sardine larvae collected in west ( ) and south-southeast $(\triangle)$ of São Sebastião area, during summer 1994. $\boldsymbol{\star}=$ significant differences between larvae collected in the areas $(\mathrm{p}<0.05)$.

The results presented in this study could identify larvae in bad feeding and nutritional condition mainly in the west coastal area of São Sebastião Island, under influence of coastal waters. On the other hand, larvae in very good condition were found in the middle continental shelf of São Sebastião Island, including larvae collected on the surface layer. These differences in larval condition around São Sebastião Island could be explained by the course of the South Atlantic Central Water (SACW) intrusions over south and southeast areas of São Sebastião. Furtado et al. (1996) described a submerged paleo channel starting from the southern mouth of São Sebastião Channel that extends southeastward on the continental shelf. This paleo valley is the main route for the bottom and enriched South Atlantic Central Water intrusion in the São Sebastião Island region, increasing the production of the area.

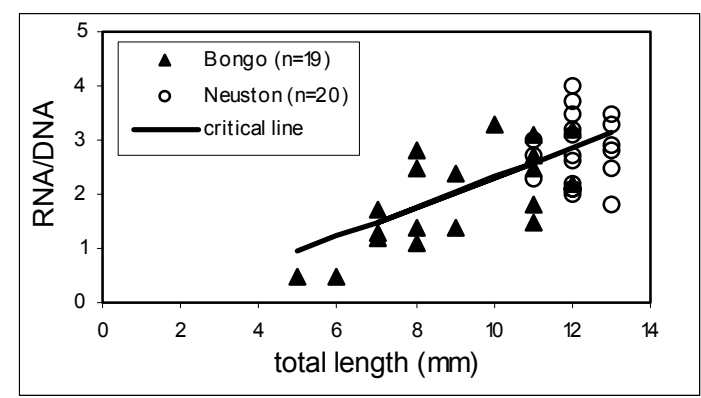

Fig. 6. Individual RNA/DNA of field Brazilian sardine larvae collected in São Sebastião region. Critical line was taken from Rossi-Wongstchowski et al. (2003).

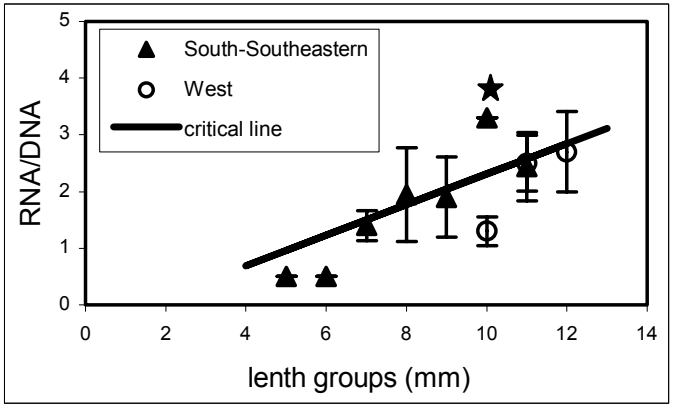

Fig. 7. Mean RNA/DNA values by lenthg groups of field Brazilian sardine larvae collected in São Sebastião region in West (O) and South-Southeastern ( $(\boldsymbol{\Delta})$ during summer 1994. * $=$ significant differences between larvae collected in the areas $(\mathrm{p}<0.05)$.

In spite of the small number of larvae analyzed in the west area, due to the high number of dead larvae collected, the application of biochemical indicators tryptic enzyme activity and RNA/DNA detected relative differences in the number of larvae in good and in poor feeding and nutritional condition in inner and middle continental shelf of São Sebastião. The middle shelf seemed to be a more favorable area for the Brazilian sardine larvae during summer 1994, due to a weak intrusion of the cold water mass over the middle continental shelf only. Larvae found at southsoutheastern of São Sebastião Island should have had higher survival probabilities than the inner shelf coastal-western ones. 
Brazilian sardine larvae can feed on the most abundant food particles available, adapting their diet (Kurtz \& Matsuura, 2001), but in the west area of São Sebastião the high percentages of dead larvae can be explained by the fact that this is an area of lower prey availability, with the lowest zooplankton density and phytoplankton biomass, in contrast to the middle continental shelf (GianesellaGalvão et al., 1997). The processes that assist larval survival, i.e. enrichment, food concentration and retention (Bakun \& Parrish, 1990), were present only in the areas under the SACW influence. Additionally, a potential competitor, the scaled sardine larvae (Harengula clupeola) were the most abundant and dominant species in the region, mainly in coastal areas (Katsuragawa \& Dias, 1997).

Based on the results of biochemical indicators and the lost of larvae, represented by 24 to $63 \%$ of dead larvae collected, we can conclude that starvation is an important source of Brazilian sardine larval mortality in the coastal area of São Sebastião Island.

\section{AcKNowledgements}

The first author wishes to thank M.Sc. Michael K. Itagaki and BSc. Clarice L. Lopes for their assistance during the collection and sorting of sardine larvae in the field, to the crew of the R/V "Prof. W. Besnard" and to Prof. Dr. Yasunobu Matsuura ${ }^{\dagger}$. We would like to thank the Instituto Oceanográfico (Universidade de São Paulo) and the Institut für Meereskunde (Universität Kiel) and the anonymous reviewer for improving the manuscript. Financial support for the OPISS Project was provided by FAPESP (Fundação de Amparo à Pesquisa do Estado de São Paulo). Biochemical analyses were performed during the course of the Brazilian-German Science and Technology Co-operation in Marine Sciences (MCT$\mathrm{CNPq} / \mathrm{WTZ}$ ).

\section{REFERENCES}

Aidar, E.; Gaeta, S. A.; Gianesella-Galvão, S. M. F.; Kutner, M. B. B. \& Teixeira, C. 1993. Ecossistema costeiro subtropical: nutrientes dissolvidos, fitoplâncton e clorofila-a e suas relações com as condições oceanográficas na região de Ubatuba, SP. Publção esp. Inst. oceanogr., S Paulo, (10):9-43.

Bakun, A. \& Parrish, R. H. 1990. Comparative studies of coastal pelagic fish reproductive habitats: the Brazilian sardine (Sardinella aurita). J. cons. int. Explor. Mer., 46(3):269-283.

Castro Filho, B. M.; Miranda, L. B. \& Miyao, S. Y. 1987. Condições oceanográficas na plataforma continental no largo de Ubatuba: variações sazonais em média escala. Bolm Inst. oceanogr., S Paulo, 35(2):135-151.
Castro Filho, B. M de \& Miranda, L. B. de 1998. Physical oceanography of the Western Atlantic Continental Shelf located between $4^{\circ} \mathrm{N}$ and $34^{\circ} \mathrm{S}$. In: Robinson, A. R. \& Brink, K. H. eds. The Sea. New York, John Wiley \& Sons. v. 2, p. 209-251.

Cergole, M. C.; Saccardo, S. A. \& Rossi-Wongtschowski, C. L. D. B. 2002. Fluctuations in the spawning stock biomass and recruitment of the Brazilian sardine (Sardinella brasiliensis) 1977-1997. Rev. bras. oceanogr., 50(único):13-26.

Chícharo, M. A. 1997. Starvation percentages in field caught Sardina pilchardus larvae off Southern Portugal. Sci. Mar., 61(4):507-516.

Chícharo, M. A. 1998. Nutritional condition and starvation in Sardina pilchardus (L.) larvae off Southern Portugal compared with some environmental factors. J. expl. mar. Biol. Ecol., 225:123-137.

Chícharo, M. A.; Chícharo, L.; Vladés, L.; López-Jamar, E. \& Ré, P. 1998. Does the nutritional condition limit survival potential of sardine Sardina pilchardus (Walnaum, 1792) larvae off the north coast of Spain? RNA/DNA ratios and their variability. Fish. Res., 39:43-54.

Clemmesen, C. 1993. Improvements in the fluorimetric determination of the RNA and DNA content of individual marine fish larvae. Mar. Ecol. Prog. Ser., 100:177-183.

David, P. M. 1965. The neuston net. A device for sampling the surface fauna of the ocean. J. mar. biol. Ass. U. K., 45:313-320.

Furtado, V. V.; Bonetti Filho, J. \& Conti, L. A. 1996. Paleo river valley morphology and sea level changes at Southeaster Brazilian continental shelf. An. Acad. bras. Ci., 68(supl. 1):163-169.

Gianesella-Galvão, S. M. F.; Aidar, E.; Vega-Pérez, L. A. \& Saldanha-Corrêa, F. M. P. 1997. Distribuição do plâncton na região costeira de São Sebastião. Publção esp. Inst. oceanogr., S Paulo, (41):5-14.

Katsuragawa, M. \& Dias, J. F. 1997. Distribuição do ictioplâncton na região de São Sebastião, SP. Publção esp. Inst. oceanogr., S Paulo, (41):15-28.

Kimura, R.; Watanabe, Y. \& Zenitani, H. 2000. Nutritional condition of first-feeding 1 arvae of Japanese sardine in the coastal and oceanic waters along the Kuroshio Current. ICES J. mar. Sci., 57:240-248.

Kurtz, F. W. \& Matsuura, Y. 2001. Food and feeding ecology of Brazilian sardine (Sardinella brasiliensis) larvae from the Southeasterns Brazilian Bight. Rev. bras. oceanogr., 49(1/2):61-74.

Matsuura, Y. 1986. Contribuição ao estudo da estrutura oceanográfica da região sudeste entre Cabo Frio (RJ) e Cabo de Santa Marta Grande (SC). Ciênc. Cult., S Paulo, 38(8):1439-1450.

Matsuura, Y. 1998. Brazilian sardine (Sardinella brasiliensis) spawning in the Southeast Brazilian Bigth over the period 1976-1993. Rev. bras. oceanogr., 46(1):33-43.

Moksness, E.; Belchier, M.; Clemmesen, C.; Cortés, D.; Doan, A.; Folkvord, A.; Garcia, A.; Geffen, A. J.; Hoie, H.; Johannessen, A.; Pontual, H.; Rámirez, T.; Schnack, D. \& Sveinsbo, B. 2000. Manual of tools for recruitment studies. Final Report FAIR-CT96-1371, $42 \mathrm{pp}$. 
Rossi-Wongtschowski, C. L. D. B.; Clemmesen, C.; Ueberschär, B. \& Dias, J. F. 2003. Larval condition and growth of Sardinella brasiliensis (Steindachner, 1879): preliminary results from laboratory studies. Sci. Mar., 67(1):13-23.

Shimizu, H.; Nakata, K. \& Nakano, H. 1989. Comparison of nutritional condition of sardine larvae, Sardinops melanostictus ( $\mathrm{T} \& \mathrm{~S}$ ) taken from the coastal and offshore region of the Kuroshio Current. Nipp. Suisan Gakkashi, 55(1):179.

Silva, L. dos S.; Miranda, L. B. de \& Castro Filho, B. M. de. 2001. Relatório do projeto "Oceanografia da Plataforma Interna de São Sebastião" (OPISS), Subprograma Oceanografia Física. Relat. téc. inst. Oceanogr., S Paulo, 47:1-31.

Smith, P. E. \& Richadson, S. L. 1977. Standard techniques for pelagic fish egg and larvae surveys. FAO Fish. Tech. Pap., (175):1-100.
Ueberschär, B. 1988. Determination of nutritional condition of individual marine fish larvae by analysing their proteolytic activities with a highly sensitive fluorescence technique. Meeresforsch., 32(1988):144-154.

Ueberschär, B. 1995. The use of tryptic enzyme activity measurement as a nutritional condition index: laboratory calibration data and field application. ICES mar. Sci. Symp., 201:119-129.

(Manuscript receive 20 January 2003; revised 08 September 2003; accepted 22 January 2004) 